\title{
Opinion: The Cultures of Literature and Composition: What Could Each Learn from the Other?
}

\section{Peter Elbow}

T he history of relations between composition and literature has involved a vexed tangle of misunderstanding and hurt. Both fields would benefit if we could think through some of the vexations. That's what I'm trying to do here.

But I won't talk about the most obvious problems: political and material issues of power, money, and prestige. These matters cannot be ignored, but I will mention them quickly and pass on. Composition has been the weak spouse, the new kid, the cash cow, the oppressed majority. When writing programs are housed in English departments, as they so often are, teachers of writing are usually paid less to teach more under poorer working conditions-in order to help support literature professors to be paid more to teach less under better working conditions. I'm hoping that these material vexations might be starting to recede just a bit now—as composition gets stronger and more secure, as writing programs find they can prosper outside English departments, and as literature itself struggles because of weak support for the humanities (not to mention frequent attacks on "professors" and all of higher education). Even the virus of relying on part-timers and adjuncts is increasing in mainstream literature, too. I ask only that we not forget how hard it will be to get past the deep legacy of anger, hurt, and guilt.

I won't even address the much-discussed question of whether writing and literature should marry, stay married, or divorce. My essay could be read as an argu-

Peter Elbow is emeritus professor of English at the University of Massachusetts at Amherst, where he directed the writing program. He taught at MIT, Franconia College, Evergreen State College, and SUNY Stony Brook-where he also directed the writing program. In addition to various books about writing, he wrote a book about Chaucer and one about the English profession (What Is English?). His book Everyone Can Write: Essays toward a Hopeful Theory of Writing and Teaching Writing was given the James Britton Award. With Pat Belanoff, he wrote a textbook, A Community of Writers. He served on the MLA's Executive Council and NCTE's Executive Committee. NCTE recently gave him the James Squire Award "for his transforming influence and intellectual contribution."

College English, Volume 64, Number 5, May 2002

Copyright $@ 2002$ by the National Council of Teachers of English. All rights reserved. 
ment for maintaining the marriage; and I certainly admire the situation in many high schools and a few smaller liberal arts colleges where members don't actually feel a tension between literature and composition. But I hope my thoughts will be of use, whatever the contractual or sleeping arrangements are between literature and composition.

I turn away here from those issues and seek instead to explore what might be called — very loosely - the cultures or traditions or identities of literature and composition. I'm interested in the intellectual and psychological traditions of these fieldsnot just practices but what I sense still lurks in our minds and in the air when we experience ourselves as "literature persons" and/or "composition persons." My ultimate goal is to answer some practical professional questions: What does the tradition or culture of literature have that composition needs? What does composition have that literature needs? How could each learn from the other?

I must confess at once that I am writing from a personal and subjective point of view. Worse yet, this essay is an exercise in large arguable generalizations (one reviewer called them "too easy") based on my "feel" or "sense" of things over the years-rather than on scholarship and research in the manner of Graff and Scholes. I present no proof; only a pudding. If my generalizations don't ring usefully true to many members of both communities, I've simply failed. Still, my subjectivity is based on forty years' teaching at six colleges or universities—and consultations, talks, and workshops at countless others.

I started full-time college teaching in 1960 and, having made it to age sixty-six, I've retired from full-time university employment. I'm continuing busy in my professional career, but this new step makes me look back. One thing I notice is my recurring sense of being torn between my identities as a literature person and as a composition person. I've long been seen as a composition person, and I've been a writing program director at two universities. But all my training was in literature, my first book was about Chaucer, and I didn't experience myself as a member of the "field of composition" till at least twenty of these past forty years had passed.

I.

I start with a sentence that makes me nervous (although I enjoy how it links the personal and professional): "I miss literature." What do I mean? First, it's just literal: I miss having works of literature central in some of my teaching. Why should I be nervous to say this? The problem is not so much sounding disloyal as being actually misleading. For when I say "I miss literature," it will sound to many as though I am voicing a whole complex of other thoughts that people in composition so often hear from people in literature: "I can't stand reading student writing." "Students have nothing of significance to write about." "No one could really get intellectually interested 
in student writing." "We can't teach students to write unless we give them models of good writing by good authors to imitate." How do I say, "I miss literature," without saying any of these other things that seem toxically false?

I miss the comfort and pleasure of planning a whole class around a literary text, and preparing for class by simply immersing myself in it as deeply and carefully as I can and preparing generative questions (assuming that I already possess enough background secondary knowledge). The goal in preparing is the same as the goal for the class: not just to understand but to try to get inside of and be stretched or even transformed by a text that is miraculously good.

As a teacher of writing, I focus on texts in class that are fruitful and interesting (student writing and published essays about writing and other topics), and they can stretch us-not the least, student writing. But these texts are seldom transcendent or magical the way so many works of literature are. They seldom make me choke up.

Yet since I've become a composition person, I've come to use a richer process for class planning. I plan by devising workshop activities designed to create experiences: all kinds of writing exercises, out-loud readings, and various kinds of work in peer groups or pairs. Class planning feels more like trying to manage complex activities than quiet immersion in an amazing text. This approach to teaching that I learned as a teacher of writing tends to result in classes that are more lively and active than my old literature classes: fewer dead spells, less tooth pulling, less talk from me, more learning. I know now, of course, that this difference is a historical accident. I can now teach a "product" of literature by using active, experiential workshop activities I learned as a teacher of writing - and thereby increase the chances of students' actually experiencing the literary work and the critical concepts we are studying. A fair number of literature teachers have learned to do the same, but I think the field of composition gets some of the credit for this. (See When Writing Teachers Teach Literature [Young and Fulwiler], which contains my "Breathing Life into the Text.")

Process and Product. People in composition have taken to using rubber gloves for the word "process" ("Oh, we're way beyond the 'process approach'!"), but an emphasis on process is ineluctably in the blood stream of composition. (Similarly, no one in literature would be caught dead identifying as a New Critic, but the profession has permanently digested that essential methodological contribution of close reading for the sake of focusing on the usually complicated relationship between what's stated and what's implied. New Criticism and the focus on writing process were surely the founding — and I dare say defining — events of the two professions as they presently exist.) Almost every literature class is about a "product," a text, and the literature teacher usually wants the students to carry away a product too-some summarizable knowledge about that text. Almost every writing class is about a process, and the writing teacher usually wants the students to carry away some increased skill in that process. Of course literature teachers seek to teach the process of read- 
ing, but I think my rough contrast is supported by a glance at two characteristic teaching practices in the two fields. In literature classes, lecturing is extremely common. It's rare or absent from writing classes. Literature exams rarely ask students to read a new text; they usually focus on works the students have already studied —and heard the teacher's conclusions about. Writing exams (if used at all) ask students to write a new text.

Still, "I miss literature" in another sense. I miss living in a culture that considers the metaphorical and imaginative uses of language basic or primal. Owen Barfield wrote a useful essay about the "invention" of literal language, arguing that metaphor came first as the default, and literal language was a late development achieved only through a complex process of mental and linguistic differentiation. I'm not saying that the culture of composition ignores metaphor and imaginative language altogether. People in the field usually acknowledge that such language helps essays do their discursive work; and some teachers invite students to write a story at the start of the semester. But I'm sad that the composition tradition seems to assume discursive language as the norm and imaginative, metaphorical language as somehow special or marked or additional. I'd argue that we can't harness students' strongest linguistic and even cognitive powers unless we see imaginative and metaphorical language as the norm-basic or primal.

Yet I found I was pleased and proud when I was drawn away from literature by my growing interest in writing. When I finally came to see myself as a composition person, I felt an enormous relief at finally feeling useful-as though I could make an actual difference for people. I'd never felt solidly useful trying to teach and write about literature. I'm proud that composition is the only discipline I know, outside of schools of education, where members feel their field has a built-in relationship to teaching and to students.

I fear, in fact, that the culture of literary studies still carries a bit of that traditional implication that there is something "lower" about teaching than scholarship; that the tone of a scholarly essay is reduced if there is talk about teaching; and that teaching issues are for the less able. People in literature are more likely than those in composition to make a distinction between teaching and their "real work." George Levine, introducing the new journal Pedagogy, meditates at length on the phrase "my work," and how people in literary studies tend to use it to mean research rather than teaching - in explicit contrast to people in composition (10). David Bartholomae points out tellingly that at the beginning of the twentieth century, when the profession of "English" was still primarily philological and not yet "literary," the teaching of writing was taken very seriously at the highest levels. But then, "Composition fell out of sight of the MLA and most of the other significant venues of professional discussion" ("Composition" 1952). 
The culture of composition carries a concern not just for teaching but also for students: attention, interest, and care for them, their lives, and what's on their minds. The core activity in teaching composition is the act of reading what's on students' minds; the core activity in teaching literature is reading the literary text. ( " $T T]$ he writing of my students and the problematic relationship between their work and the work of the academy[:] these seemed to hold all of the material I needed to make a career" [Bartholomae "Freshman" 39].) Composition teachers are more likely, when asked what they teach, to give that ornery answer: "I teach students." I'm proud that we can be a rich scholarly field and still keep these ties to teaching and students. The culture has somehow managed to build a felt value in identifying with students—or at least refusing to see them as "other." Writing is more of a leveler than reading: in writing more than reading, teachers and students tend to feel the same anxieties (see my "War between Reading and Writing").

And yet. I seem to be praising composition for being more "real" and practical, and for dealing more directly with the genuine needs of students (and also, by the way, with concerns felt by the public). I am. Yet I must turn again and choose a different lens for a different view. For in a genuine sense, the most real and practical use of language is for making stories, images, and even poems. Mark Turner, in The Literary Mind, talks of story as the primary mode of language that organizes our very minds. When we dream, we may sometimes explain or argue, but the basic language of our nightly dreams is images and stories. Imaginative language touches people most deeply; sometimes it's the only language use that gets through. When people feel the tug of wanting to write (it's too little recognized in both traditions that most people actually feel such a tug) - what most often tugs at them is the call to render experience in narratives, images, or poems. (On the burgeoning research on "everyday writing," see Barton, Bloome, Sheridan, and Street; Barton and Ivanic; Hamilton, Barton, and Ivanic.)

So literature is no less "real" or "useful" than composition. And yet sadly, I feel that the culture of literature misses the boat here. Most teachers of literature neglect the task of teaching students how to use language imaginatively - how to write stories and poems. The tradition in literature seems to declare: "Imaginative writing can't be taught-it's too mysterious" or "Only artists or geniuses create art" or "We must try to staunch the hemorrhage of second-rate writing into the world." (I sometimes sense teachers of literature trying to stamp out "bad" amateur poetry. But it's a futile effort. Huge numbers of people write it, although they usually fear to show it to most of their teachers-whether literature or composition.)

But imaginative writing can be taught—and taught well, even to rank novices. I'm not, by the way, thinking of the teaching in MFA programs-where faculty assume that their students have no trouble producing imaginative writing, and there- 
fore see their task as providing "workshops" to help students "critique" better. No, I'm thinking about a small but powerful stream of teachers in the schools (and in a few undergraduate writing courses) who are helping their students in a more generative fashion to write stories and poems and other imaginative and personal pieces. This interesting tradition has many sources. I am proud of its roots in the early days of composition-back when folks were not so nervous to talk about "creativity" or "invention." But I want to pay special homage to a crucial bridge that has carried this fragile tradition of teaching imaginative writing from the early days of composition to these important school classrooms: the so-called "area writing projects" scattered all around the country that grew from the original Bay Area Writing Project. There are now some 165 National Writing Project sites every summer, and they maintain a sturdy tradition of inviting teachers themselves to do imaginative writing of their own. (Of course they sponsor academic and critical writing, too.) This tradition of imaginative writing in the schools derives in addition from some crucially generative poets like Kenneth Koch-and from some small, powerful organizations like Teachers and Writers Collaborative and Poets in the Schools.

Not only does the literary tradition neglect the teaching of imaginative writing, it also neglects teaching us to read in such a way as to help bring powerful imaginative texts most palpably into our lives. The problem I'm speaking of could be called the "distancing mode" - the tradition of "critical reading." In the tradition of New Criticism, students are urged to look at literary works as complex artifacts rather than as devices for making sense of their lives and feelings. In addition, postmodernist and deconstructive practices also function as ways to distance oneself from the text as a kind of intellectualized aesthetic object. In contrast, teachers in the newer and powerful tradition of cultural studies usually $d o$ try to help students use texts for making sense of their lives (and often seek texts that students feel as part of their lives already—such as popular music or TV). But even here, I often sense the tradition of distancing. The goal in cultural studies tends to be to help students read with more critical detachment-to separate themselves from felt involvement in these texts.

Thus, the culture of literary studies feels to me to work against students' impulses to involve themselves personally with literature and feel they are making personal connections with characters and authors - to feel a genuine relationship with Chaucer or Iago. I'd argue that most good readers actually do this-and that even good critics do it and take it for granted before they go on to their critical practices. But most students need belp achieving this kind of personal entanglement with texts.

I imagine readers of College English resisting me here and arguing that the problem with students is that they already identify too much — that they lack the ability to question and to achieve critical distance-to read against the grain. But the validity of this objection papers over a crucial distinction. Yes, students often don't read 
against the grain; but that doesn't mean they are good at reading with the grain. Lack of critical distance is not the same as full, rich involvement. For all too many students, the text is a pretty "nothing" experience. Why should they be interested in learning to question or see contrary depths in a "nothing" experience? I'm not making an either-or argument against critical detachment; I'm arguing that most students need help learning how to enter into mentalities and experience points of view different from their own (see Nemerov; see also my essays about "the believing game" or "methodological belief").

We can better notice the distancing dimension in the culture of literary studies if we compare it to the work of Robert Coles. A psychoanalyst and scholar in many fields, he describes in The Call of Story how he teaches literature to Harvard undergraduates and medical and business students as ways to help them work through larger ethical questions of life and work (see also O'Connor's "Words and the World at a New York Public School: Can Writing Really Matter to Inner City Children?”). I'm not suggesting that teachers of literature abandon the use of all distancing techniques; I'm suggesting the need for what is almost entirely neglected, namely "involving" techniques (as in much of Young and Fulwiler).

Speaking of distance, let me stand back now and meditate for a moment on the two essential dimensions of language use that I have been implying here: rhetoric and poetics. In one sense, all language is rhetorical; Wayne Booth made it clear that even literature has designs on readers-argues, does business. But the tradition from Nietzsche and I. A. Richards provides the opposite lens to help us nevertheless see that all language use is also an instance of poetics: a figurative or metaphorical structure that characteristically yields up more meaning or pleasure when we see it as a self-contained or intertextual structure-one that always means more than it purports to mean. (Deconstructive critics-wisely or perversely? - define rhetoric itself as figurative language or poetics.) Once we stand back this way, it's obvious that neither rhetoric nor poetics is better. What's sad is that a discipline devoted to understanding language use should tend to restrict itself to one lens.

I'll end Section I by summarizing what I wish the cultures of literature and composition might learn from each other:

- I wish the culture of composition would learn to give an equally central place to the imaginative and metaphorical dimensions of language. And I don't want my emphasis on stories and poems to obscure my larger emphasis on all language-even if the only goal is teaching essays. Surely many of the best and most effective essays don't just make good use of metaphors and images; rather, they grow out of imaginative metaphorical thinking - out of the imagination itself. But we won't understand the craft of such essays unless we feel their roots in the imagination rather than only in clear logical thinking and language.

- I wish the culture of literature would learn more inherent attention and concern for students - their lives and what's on their minds. If it did, I think teachers of literature 
would give more attention to helping students read with involvement and write imaginative pieces. Even if our only goal is to get students to understand a work of literature, nothing works better than inviting students to write stories or poems that are structurally, thematically, or rhetorically related to it (see my "Breathing Life into the Text").

\section{II.}

I fear I sound hopelessly corny and naive. I hear a contrary voice even in my own mind: "But your only use for literature is in fact to use it-for personal therapy. You want everything to be utilitarian and pragmatic. You're just a cornball-blind to all the sophistication in the literary tradition."

Sophistication. Yes. Just as I started off saying I miss literature, so too I miss sophistication. I miss elegance and irony and indirection-qualities that composition has sometimes reacted against. My dissertation and first book were about complex or double irony in Geoffrey Chaucer. What I love about Virginia Woolf is not just that she finds words for the felt texture of human experience but that she somehow embodies mental rawness in such elegance and sophistication.

But just as loving literature has gotten itself all tangled up with a noxious tradition of failing to value students and their writing and thinking, so, too, loving sophistication is all tangled up with an equally noxious tradition of condescension, snobbery, and elitism. Let me explain.

When I was trained in literature, both as an undergraduate and as a graduate student, I felt a subtle but insidious pressure: if I wanted to be good in this field, I had to learn somehow to be a slightly different kind of person from who I wassomehow "not ordinary." I happened to have had the right gender, race, sexual orientation, and a more or less acceptable accent, but I still felt I was supposed to learn to be in some subtle internal sense different_-somehow "higher" or "finer."

That was a long time ago. Perhaps I can be convinced that this aura is no longer in the air, but I still feel in many departments and seminar rooms today that old feeling: that training in literary study is not just learning knowledge and skills but learning to stop being "ordinary" or "regular" and instead be more sophisticated and even oblique. Close reading, highly refined perception, and fine-tuned awareness of nuance: these usually involve the ability to process texts and ideas not just with your intellect or thinking but with your self or sensibility. All this often shades over into a value system that asks aspiring graduate students to have a better sensibility or self. "Better" sometimes connotes "more cultured," slightly "higher class" even more conservative. Sometimes it connotes something leftist or politically correct. Political correctness is strong in composition too, but somehow I don't feel in this culture the same faint pressure to be different or feel different as people-somehow faintly to improve or abandon who we are. 
I've always sensed that this training in sensibility or taste that we get in literary studies explains why people with literary training take everything so personallyand why English departments are so remarkably rancorous: if you disagree with my reading of a text or my judgment about a theory, you aren't just criticizing my thinking, you are impugning my very self-as-sensibility. (Cathy Davidson, having moved from being a chair to being a vice provost writes: "From conversations I've had with administrators across the country, I know that, relative to other departments, English departments are frequently embattled" [102].) If you fail to appreciate what's good or if you like what's bad, there is something wrong with you-not just your opinions. Taste is feeling and sensibility, not just thinking. What does it mean to have better taste if not to have your teeth set on edge by more things than the other person? (Is there any other discipline than English that has cast off so many subgroups that used to be integrally part of it? Speech, communication, theater, film, ethnic studies, women's studies - not to mention a professional or technical interest in the nature of language? ${ }^{2}$ Interestingly, literary studies now hankers for a piece of theater's turf: performance studies.)

And yet I have to turn again. I love it that I got training in a culture that asked me to develop not just my thinking skills but my ability to attune my every fiber to the text or the idea at hand. It's a common failure of rationality or intelligence to restrict the definition of rationality to the exercise of conventional reasoning. Frankly, I credit widespread literary training with the fact that so many people in composition take emotion so seriously and insist on links between feelings and cognitionand haven't allowed the powerful war against the personal dimension in writing to be won. And there's no doubt that my literary training gave rise to one of my main preoccupations and areas of research in composition: "voice" in writing. (Interestingly, I've found in linguistics the most compelling empirical evidence that humans tend to put their individual stamp on the language they use. I'm thinking of a remarkable book, The Linguistic Individual: Self-Expression in Language and Linguistics, by Barbara Johnstone.)

Let me briefly focus my attention on a particular thread in the larger weave of sophistication: high. What better word than "high" to connote all the condescension people in composition often feel from literary folk-and to connote the elitism and snobbery that so many people at large have felt in the culture of literary studies. From on high, we can look down. Yet again I turn. I can't throw away "high." I want to value it and keep it-yet peel away what's noxious. Is there not something valuable that follows from revering and even trying to live with things one experiences as "above" one-Milton? Woolf? Morrison?-from trying to get our minds around things that are miraculously good? Edward Said, no conservative, insists baldly that the word "exalted" has "a particular resonance for me"-and quotes Michael Fried on the "unshakeable conviction in the supreme achievement and absolute impor- 
tance of certain works of art" (7). When we try to give full attention to such works, I think we are likely to feel the need to "give in" to them, to submit, to play the believing game. So even though I fight elitism, I still want to value "high." The problem is the temptation to feel "higher than others" if one appreciates high and subtle things they don't appreciate-whereas true awareness of the high ought to make us feel low.

Let me pull a different thread from the weave of sophistication: style. And with it, artificiality, artifice, mannerism. The culture of literary studies puts a high value on style and on not being like everyone else. I think I see more mannerism, artifice, and self-consciousness in bearing (sometimes even slightly self-conscious speech production) among literary folk than composition folk. Occasionally I resist, yet I value style and artifice. What could be more wonderful than the pleasure of creating or appreciating forms that are different, amazing, outlandish, useless-the opposite of ordinary, everyday, pragmatic? Every child is blessed with an effortless ability to do this: it's called play.

So I miss sophistication; and yet I fight back when people in literature condescend to composition as unsophisticated. I am proud of what I sense as a kind of resistance to sophistication - a kind of allergy - that I feel in the culture of composition. (The last chapter of my Chaucer book is about how he relinquishes irony.)

Uh oh. Does it sound as though I'm painting composition as a culture of innocent, childlike naiveté? I don't mean that; it has its share of skepticism and even corruption. Still, I'd insist that there is a genuine naiveté, corniness, or innocence in the world of composition, and I value it and wish more literature people could learn it. Is it not naive in the best sense to think we can truly identify with our students? Is it not corny to think we can be or can strive to be "like everyone else" or "regular"? That we can transmit the power of literacy to everyone? That we can be a democratic or egalitarian force to change society? These are values deep in the culture of composition.

Let me move toward my ending with another tiny meditation. Just as rhetoric and poetic are two essential dimensions of language, so sophistication and naiveté (or refusing sophistication) are two ways of being in the world: we can be complex, sophisticated, ironic, and adorn ourselves with style and artifice; or we can be naked, naive, and direct. Here again I'm trying to escape either-or thinking-escape the tired habits in which the sophisticated look down on the naive, while the naive look back down just as haughtily. There's no need for higher or lower, better or worse, with these two ways of being. We can have sophistication without snobbery, elitism, or condescension; we can have naive and open identification with everyone else, and yet not neglect intelligence, complexity, and careful thinking. And it is perfectly feasible for both cultures, literature and composition, to help both styles to flourish. ${ }^{3}$ 
So I wish more people in literature could learn less pretension and more acknowledgment that, really, we are all like one another-driven by the same basic need to be loved and heard. I wish the culture of literary studies gave more honor to the courage of just sitting with, attending to, or contemplating a text—or enacting or performing it without any striving for an interpretation. And I see signs for hope that more people in literary studies are on their way to giving more honor to being pragmatically useful in the world-for example, with the recently awakened interest in the training of teachers of English.

And what do I wish people in composition could learn from the culture of literature? More honoring of style, playfulness, fun, pleasure, humor. Better writing - and a more pervasive assumption that even in academic writing, even in prose, we can have playfulness, style, pleasure-even adornment and artifice-without being elitist snobs.

There's also a piece of scholarly sophistication I wish composition could learn from literary scholarship. I've noticed in composition scholarship a tacit acceptance of reductive oversimplifications about historical periods and movements (for example, claims that take the form of "Romanticism meant ..." or "Romantics believed ...")—and readings of important historical figures (claims that "Plato said ..." or "Aristotle said ...") based only on quotations from a reductive secondary source. It's almost as though people in composition insist on more care and respect for student texts than for texts from large figures from distant historical eras.

Finally, I think both cultures can learn from each other with respect to their status as disciplines. I have a vision of composition and literature passing each other on opposite escalators at Macy's. Just as composition is achieving disciplinary strength, literary studies is relinquishing whatever pretensions it had for disciplinary coherence-and sometimes seems in fact to be disintegrating as a discipline. Literary studies has become more and more a motley crew thrown together by history and change.

Composition, on the other hand, started out as nothing but a motley collection of people historically thrown together (mostly by teaching exigencies) who even now continue to call on an amazing array of disciplines: rhetoric (classical and modern), linguistics, literary studies, history, philosophy, psychology, education, and others. There is still no preferred methodology, paradigm, or point of view. Different members use historical investigation, quantitative research, qualitative/ethnographic research, and textual studies (hermeneutic and theoretical) of the sort traditionally practiced in English and philosophy. For this reason-or perhaps because the field is so tainted by its commitment to teaching - the National Endowment for the $\mathrm{Hu}$ manities won't recognize composition as a field of scholarship: no one can take part in NEH activities or get any NEH support for scholarly work in the field of composition. When the Chronicle of Higher Education lists "New Scholarly Books" every 
week, it doesn't include books in composition. None of this goes for rhetoric, of course, which is old enough to see English as a recent upstart. Rhetoric is seen as coherent and untainted by teaching and is thus recognized by both the NEH and the Chronicle.

Composition is just as polyglot as it's always been, but it's on the up escalator. It's become ever more vigorous and impressive as a scholarly field in the last couple of decades and developed an amazingly coherent energy and esprit de corps - a sense of itself as a healthy undertaking marching down the road as a single enterprise. The contrast with literary and cultural studies couldn't be more striking. I admire how this has happened without composition closing ranks around a dominant vision or discipline or methodology. But I fear the hunger to be more impressive by becoming a "real discipline" in the old-fashioned sense of having a dominant vision and methodology. ${ }^{4}$ I sense the scholarly discourse having sometimes become more competitive and divisive - as though we can't be a real discipline unless some vision or methodology or paradigm "wins" - as though one paradigm can't be right unless the others are wrong. I fear the culture of composition losing its venerable tradition of "big tent" tolerant pluralism and mutual respect toward all stances. Even in 1989, David Bartholomae saw the danger of coherence-yearning: "I am suspicious of calls for coherence. I suspect that most of the problems in academic life-problems of teaching, problems of thinking - come from disciplinary boundaries and disciplinary habits [....] The charge to this generation and the next is to keep the field open, not to close it" ("Freshman" 49).

Interestingly, I see people in literary studies beginning to develop a genuine if grudging tolerance and even respect for the deep differences that have been increasing in recent decades-learning to live productively with a wildly diverse plurality of outlooks and critical and methodological practices. People in composition have always been good at this in the past but have sometimes felt it as an accidental function of oppressed status. So I wish both cultures could fully accept that a discipline can be even richer and healthier if it lacks a single-vision center. A discipline based on this multiplex model can better avoid either-or thinking and better foster a spirit of productive catholic pluralism.

What would it look like, then, for the two cultures to learn from each other? Obviously - and very hopefully_it's been starting to happen. I can't do better than to quote, with deep gratitude, from Jane Danielewicz's response to an earlier draft:

Literature and composition people need to get off those diverging escalators and join forces. Not just learn from each other but live with each other-go for integration rather than separate but equal accommodations. There's lots of movement in this direction already. Interestingly, there are a number of comp people turning up as chairs of English departments. [The field of composition often attracts community 
minded "good citizens," and writing program administration has given lots of them good experience in tricky administration. PE] We see composition and literature people team teaching; some literature professors are retooling to teach composition while comp professors are teaching lit courses. If we consider the texts people are producing, there has been an explosion in both fields of mixed genres of writing, as well as the introduction of creative nonfiction in both fields, renewed interest in the personal and in the personal essay, and attention to writing as a force (as in feminist manifestos, regional and ethnic texts such as Caribbean and Latino literatures, cultural literatures such as gay and lesbian studies, and so on). We have a chance now and ought to run with the momentum generated by current circumstances (even negative ones such as budget cuts in the humanities) to find ways of working together. ${ }^{5}$

\section{Notes}

1. Thanks to Elizabeth Sargent for this point.

2. Thanks to Charlie Moran for this perspectival point.

3. Of course these are slippery matters. One of the guises of sophistication is naiveté (nakedness as high artifice), as in the genre of the pastoral. True enough; a special case, but not the whole story of plainness. I can't resist citing a piece of work that admirably defies these two categories. It's a literary essay that stakes out a stance called and even claimed as naive (insisting on treating "the speaker" in a poem as "the author"), but that enacts far more grace, sophistication, and learning than most writers who might charge it with naiveté: Clara Claiborne Park's "Talking Back to the Speaker."

4. A large coalition of writing program administrators from across the country has pulled off an impressive job of collaboration in producing a single "outcomes statement" for first-year writing courses. Of course first-year writing is not the same as the large field of composition, and the administrators are not trying to produce a uniform curriculum. Their goal is only to clarify thinking (and I've written "A Friendly Challenge to Push the Outcomes Statement Further" for their planned book about it), but I fear the pressure of orthodoxy that such impressive unity might engender. For the outcomes statement, see the Works Cited.

5. My deep thanks go especially to Jane Danielewicz, but also to Sheridan Blau, Joe Harris, Charlie Moran, Jean Nienkamp, Irene Papoulis, Elizabeth Sargent, and College English readers—and others-for helpful responses to drafts.

\section{Works Cited}

Barfield, Owen. "The Meaning of the Word 'Literal'." Metaphor and Symbol. Ed. L. C. Knights and Basil Cottle. London: Butterworths, 1960.

Bartholomae, David. “Composition, 1900-2000.” PMLA 115 (2000): 1950-54. "Freshman English, Composition, and CCCC." CCC 40 (1989): 38-50.

Barton, D., David Bloome, D. Sheridan, and Brian Street. Ordinary People Writing: The Lancaster and Sussex Writing Research Projects. Working Paper Ser. 51. Lancaster, England: Centre for Language in Social Life, Dept. of Linguistics and Modern English Language, Lancaster U, 1993.

Barton, David, and Roz Ivanic. Writing in the Community. Newbury Park: Sage, 1991.

Coles, Robert. The Call of Stories: Teaching and the Moral Imagination. Boston: Houghton, 1989.

Davidson, Cathy N. "Them versus Us (and Which One of 'Them' Is Me?).” Profession 2000: 97-108. 
Elbow, Peter. "Breathing Life into the Text." When Writing Teachers Teach Literature. Ed. Art Young and Toby Fulwiler. Portsmouth: Heinemann Boynton, 1995. 193-205. Rpt. in Everyone Can Write: Essays toward a Hopeful Theory of Writing and Teaching Writing. Ed. Peter Elbow. New York: Oxford UP, 2000. 360-71.

. "The Doubting Game and the Believing Game." Appendix. Writing without Teachers. New York: Oxford UP, 1973. 147-91.

. "Methodological Doubting and Believing: Contraries in Inquiry." Embracing Contraries: Explorations in Learning and Teaching. New York: Oxford UP, 1986. 254-300.

. "The War between Reading and Writing—and How to End It." Rhetoric Review 12 (Fall 1993):

5-24. Rpt. in Everyone Can Write: Essays Toward a Hopeful Theory of Writing and Teaching Writing. Ed. Peter Elbow. New York: Oxford UP, 2000. 281-99.

Graff, Gerald. Professing Literature: An Institutional History. Chicago: U of Chicago P, 1987.

Hamilton, Mary, David Barton, and Roz Ivanic. Worlds of Literacy. Toronto: Ontario Institute for Studies in Education, 1994.

Johnstone, Barbara. The Linguistic Individual: Self-Expression in Language and Linguistics. New York: Oxford UP, 1996.

Levine, George. "The Two Nations." Pedagogy: Critical Approaches to Teaching Literature, Language, Composition, and Culture 1 (Winter 2001): 7-19.

Nemerov, Howard. "Speaking Silence." New and Selected Essays. Carbondale: Southern Illinois UP, 1985. 49-55.

O'Connor, Stephen. "Words and the World at a New York Public School: Can Writing Really Matter to Inner City Children?" Teachers and Writers 32.2 (Nov.-Dec. 2000): 1-8.

“Outcomes Statement." WPA: Writing Program Administration 23 (1999): 59-70.

Park, Clara Claiborne. "Talking Back to the Speaker.” Hudson Review 42.1 (1989): 21-44. Rpt. in Landmark Essays on Voice and Writing. Ed. Peter Elbow. Hermagoras, 1994. 139-56.

Said, Edward. "Scholarship and Commitment: Introduction." Profession 2000: 6-11.

Scholes, Robert E. The Rise and Fall of English: Reconstructing English as a Discipline. New Haven: Yale UP, 1998.

Turner, Mark. The Literary Mind. New York: Oxford UP, 1996.

Young, Art, and Toby Fulwiler. When Writing Teachers Teach Literature: Bringing Writing to Reading. Portsmouth: Heinemann Boynton, 1995. 